University of Montana

ScholarWorks at University of Montana

6-2005

\title{
Stress Tolerance and Competitive-Response Ability Determine the Outcome of Biotic Interactions
}

Pierre Liancourt

Ragan M. Callaway

University of Montana - Missoula, Ray.Callaway@mso.umt.edu

Richard Michalet

Follow this and additional works at: https://scholarworks.umt.edu/biosci_pubs

Part of the Biology Commons

Let us know how access to this document benefits you.

\section{Recommended Citation}

Liancourt, Pierre; Callaway, Ragan M.; and Michalet, Richard, "Stress Tolerance and Competitive-Response Ability Determine the Outcome of Biotic Interactions" (2005). Biological Sciences Faculty Publications.

219.

https://scholarworks.umt.edu/biosci_pubs/219

This Article is brought to you for free and open access by the Biological Sciences at ScholarWorks at University of Montana. It has been accepted for inclusion in Biological Sciences Faculty Publications by an authorized administrator of ScholarWorks at University of Montana. For more information, please contact

scholarworks@mso.umt.edu. 


\title{
STRESS TOLERANCE AND COMPETITIVE-RESPONSE ABILITY DETERMINE THE OUTCOME OF BIOTIC INTERACTIONS
}

\author{
Pierre Liancourt, ${ }^{1,4}$ Ragan M. Callaway, ${ }^{2}$ And Richard Michalet $^{3}$ \\ ${ }^{1}$ Laboratoire d'Écologie Alpine (LECA), UMR 5553 CNRS-Université Joseph Fourier, BP53X, F-38041 Grenoble \\ Cedex 9, France \\ ${ }^{2}$ Division of Biological Sciences, University of Montana, Missoula, Montana 59812 USA \\ ${ }^{3}$ U.M.R. BIOGECO 1202 INRA-Université Bordeaux 1, Avenue des Facultés, 33405 Talence Cedex, France
}

\begin{abstract}
Theoretical models predict that the net outcome of biotic interactions among plants is the sum of co-occurring negative and positive interactions, with facilitation generally increasing in importance with increasing abiotic stress. However, species differ in fundamental niche optima; thus the intensity of stress is relative among species and important only in the context of these relative differences. We tested the hypothesis that the facilitative response of a species is relative to how much abiotic conditions deviate from the optimum conditions for that particular species (stress), and the competitive "response" ability of the species (i.e., its ability to tolerate the inhibitory effects of neighbors). In a field experiment, we examined the responses of three co-occurring species with different ecological optima, Bromus erectus, Brachypodium rupestre, and Arrhenatherum elatius, to the alleviation of a primary limiting resource (water), and to biotic interactions in a mesoxeric grassland in eastern France. We found that $A$. elatius had a strong positive response to watering, the response of $B$. rupestre was moderately positive, and $B$. erectus did not respond significantly, suggesting that water stress was only important for the first two species. Most importantly, the net outcome of the interaction between each species and its neighbors depended on the degree of water stress it experienced in its natural habitat. For survival, in the control plots we found no significant interactions for B. erectus (not stressed) whereas $B$. rupestre and $A$. elatius (stressed species) were facilitated. Enhancing water availability suppressed facilitation of $B$. rupestre and $A$. elatius and led to competitive exclusion of $B$. erectus. In contrast to survival, there was no facilitation for growth in the control plots, and competition intensity increased for all three species with watering. In our experiment the competitive response of a species was inverse to its ability to tolerate stress, indicating a trade-off between these components of the species response. A facilitative outcome appears to be a function of a species having both a low tolerance to a particular abiotic stress and a strong competitive-response ability.
\end{abstract}

Key words: Arrhenatherum elatius; Brachypodium rupestre; Bromus erectus; competition; competition interactions and stress; competitive response; distributional optima; facilitation; field experiment; grassland; stress tolerance; water relations.

\section{INTRODUCTION}

The importance of positive interactions in abiotically stressful environments is widely recognized (Bertness and Hacker 1994, Choler et al. 2001, Callaway et al. 2002; but see Tielbörger and Kadmon 2000, Hastwell and Facelli 2003, Maestre and Cortina 2004). The severity of the physical environment represents a primary limitation on plant fitness, and by improving environmental conditions facilitation can be of crucial importance in many physically harsh habitats (Callaway 1995). Despite the common net facilitative effect in harsh environments, many empirical studies have demonstrated that positive and negative interactions cooccur in harsh environments (Walker and Chapin 1986,

Manuscript received 8 September 2004; revised 27 October 2004; accepted 29 October 2004. Corresponding Editor: S. C. Pennings.

${ }^{4}$ E-mail: pierre.liancourt@ujf-grenoble.fr
Holmgren et al. 1997, Holzapfel and Mahall 1999, Pugnaire and Luque 2001, Dormann and Brooker 2002, Maestre et al. 2003). The net effects of biotic interactions are the sum of these negative and positive interactions (Brooker and Callaghan 1998), with the balance between competition and facilitation often depending on the harshness of the physical environment (Bertness and Callaway 1994).

Despite the generality of the stress-facilitation relationship, species differ in their physiological and ecological optima, and thus stress is relative to a particular species, and perhaps important only in the context of other species (Corcket et al. 2003, Lortie et al. 2004). In a multi-species assemblage, some species are close to their optimum while other species are not. Choler et al. (2001) demonstrated that the competitive or facilitative effects of neighbors in alpine communities depended on where experiments were conducted relative to the distributional optimum of the target species. 
Facilitation was common when species were near their upper distributional limits and competition was common where species were near their distributional optima or lower in elevation. If highly stress-tolerant species are experimental targets where the abiotic conditions are not particularly harsh for that species, then competition may be expected. Similarly, Pennings et al. (2003) argued that salt-tolerant species are unlikely to benefit much from neighbor amelioration of soil salinity. Biotic interactions may vary from negative to positive as a function of the ability of a species to tolerate particular abiotic conditions (Bertness et al. 1992, Hacker and Bertness 1999).

On the other hand, species also differ in their ability to tolerate the inhibitory effects of neighbors-i.e., "competitive response ability" (Goldberg and Landa 1991). As modeled by Brooker and Callaghan (1998), a high competitive-response ability may enable a species to minimize the cost of negative interactions and thus to maximize the benefits of habitat amelioration by neighbors. However, in particularly harsh environments, similar beneficial effects have been observed for slow-growing shrubs known to have a low competitive-response ability (Maestre et al. 2001, Castro et al. 2002). To our knowledge, no empirical studies have experimentally evaluated the relationship between facilitation, competitive-response ability, and stress tolerance for species differing in ecological optima, but co-occurring in the same habitat.

Mesoxeric European calcareous grasslands are well suited to test this relationship. Hillier (1990) documented shifts between facilitation and competition along a natural gradient of water availability in grasslands in Great Britain. Bromus erectus (Hudson) dominates the xeric end of the gradient, Brachypodium rupestre (Host) Schubler and Martens dominates the mesic nutrient-poor end of the gradient, and Arrhenatherum elatius (L.) dominates the mesic and nutrient-rich end of the gradient (Royer 1987). However, the three species commonly co-occur in mesoxeric grasslands where $B$. erectus tends to be the most abundant of the three species. Based on abundance, $B$. erectus should be the closest to its ecological optimum, whereas these environmental conditions should be less than optimal for B. rupestre and A. elatius. Moreover, B. erectus has been described as more drought tolerant (Grime et al. 1996) than B. rupestre (Grime and Campbell 1991, Corcket et al. 2003) or A. elatius (Grime and Curtis 1976).

In order to test our hypothesis that stress tolerance and competitive-response ability determine the outcome of biotic interactions for a focal species, we performed a removal experiment coupled with resource manipulation in the field. We predicted that (1) B. rupestre and $A$. elatius should be facilitated by neighbors, (2) B. rupestre and A. elatius would be positively affected by the watering treatment, but $B$. erectus would not, and (3) the target species with the highest com-

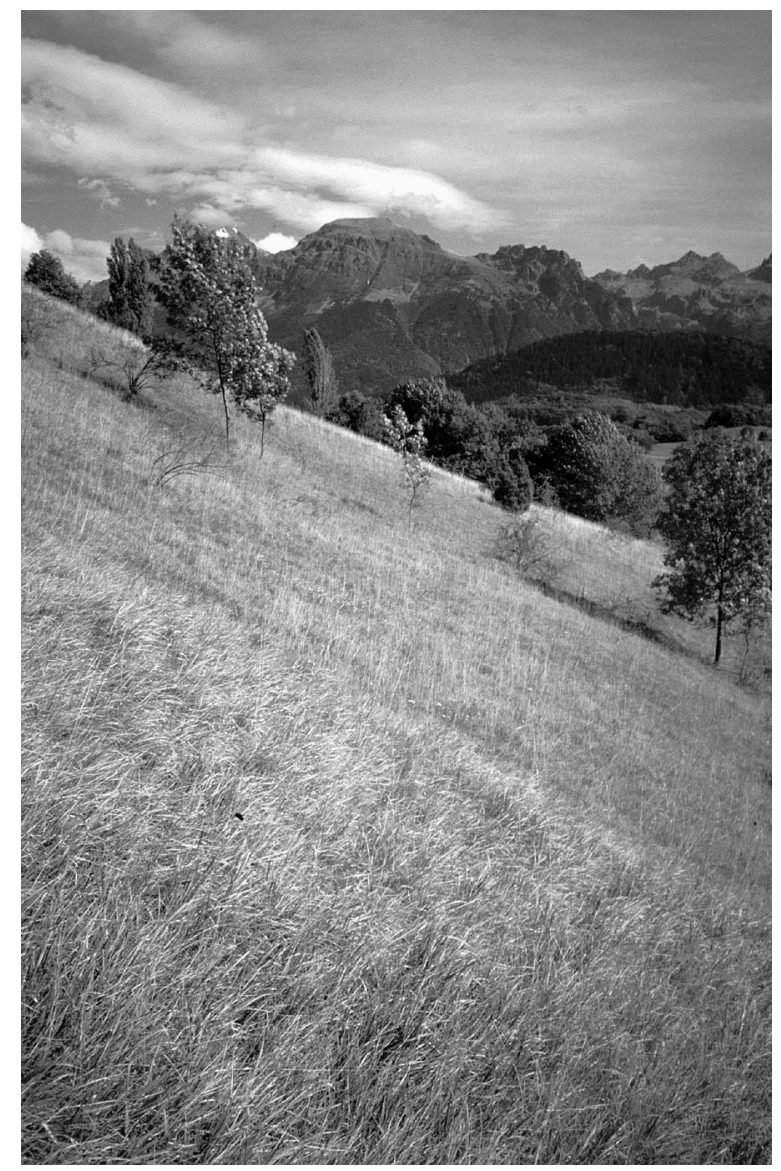

Plate 1. Ecotone between a Brachypodium-dominated community (foreground) and a Bromus-dominated community on the calcareous foothills of the Belledonne range (background). Photo credit: Emmanuel Corcket.

petitive-response ability should demonstrate the strongest facilitative response to neighbors. In summary: the net outcome of biotic interactions and the balance between positive and negative interactions should shift with resource availability, but this shift should be species-specific and dependent on the "strategy" of the target species.

\section{Methods \\ Study site}

The experiment was performed in a typical speciesrich mesoxeric calcareous grassland on the foothills of the Belledonne range, $15 \mathrm{~km}$ southeast of Grenoble, France (700 $\mathrm{m}$ above sea level [a.s.1.]; 45 $10^{\prime} \mathrm{N}, 5^{\circ} 50^{\prime}$ $\mathrm{E}$; see Plate 1). In Grenoble (210 m a.s.1.) mean extreme temperatures run from $-2{ }^{\circ} \mathrm{C}$ in January to $27^{\circ} \mathrm{C}$ in July. Mean annual precipitation is $1300 \mathrm{~mm}$, summer precipitation (June-August) $300 \mathrm{~mm}$, and insolation is 1900 h/yr (Météo-France 2001, 2002). The site, called Lichepetet, has a southwest exposure with an average slope of $25^{\circ}$. The soil is deep $(1 \mathrm{~m})$ but well drained, the upper layer $(0-30 \mathrm{~cm})$ containing $38 \%$ sand, $35 \%$ 
silt, $20 \%$ clay, and $7 \%$ organic matter, and the deepest sandy layer containing gravel and numerous stones. This soil is nitrogen poor (1.84 $\mathrm{mg}$ of available $\mathrm{N}$ per kilogram of dry soil) and quite uniform throughout the field site (Corcket et al. 2003). As in many other European mesoxeric calcareous grasslands (Royer 1987), the two dominant grass species are Bromus erectus (55-60\% cover) and Brachypodium rupestre (10-15\% cover). Nitrogen-demanding grasses (e.g., Arrhenatherum elatius, Dactylis glomerata, and Holcus lanatus) have a very low cover $(<5 \%)$. Other species $(25-30 \%$ cover $)$ are sedges (Carex flacca, C. caryophyllea), forbs (Euphorbia cyparicias, Origanum vulgare), woody species (Teucrium chamaedrys, Thymus serpyllum), and legumes (Lotus corniculatus, Medicago falcata, Medicago lupulina).

\section{The experiment}

In April 2001 we established a field experiment incorporating a split-plot design with watering as the main plot treatment and two subplot treatments, competition and species, applied within the main treatment. The grassland was surrounded by a fence to exclude the primary herbivores (deer, sheep, and rabbits) and 14 rectangular plots $\left(15 \mathrm{~m}^{2}\right.$ each, i.e., $\left.3 \times 5 \mathrm{~m}\right)$ were delimited for the main plot treatment with seven replicates per main treatment. The watering treatment was assigned randomly to the plots. To avoid a slope-induced contamination of the lower control plots by resources coming from higher treatment plots, the 14 plots were located on two elevational contours with a 5-m-wide buffer zone between the upper and lower plots. A 2-m-wide buffer zone separated adjacent plots along the same contour line. Treatment plots (seven) were watered using a permanent irrigation system, from April to September in 2001 and 2002, to avoid any water stress in these plots, whereas the seven control plots received natural precipitation only. The total amount of water received by the control plots during the summer was $348 \mathrm{~mm}$ the first year and $268 \mathrm{~mm}$ the second year, whereas the watered plots received approximately $800 \mathrm{~mm}$ each summer.

Field-collected seeds of the three target species were germinated on petri plates in a greenhouse at the beginning of March 2001. Then seedlings were transplanted into a 1:3 field site soil:grey river-sand mixture within plastic pots of $0.24 \mathrm{~L}(2.4-\mathrm{cm}$ radius and $17 \mathrm{~cm}$ height), with one seedling per pot. They were grown for one month in the greenhouse and then one month in the common garden of the university before field transplantation. During this period seedlings were watered every day.

For the species and competition treatments we located 24 circular subplots (50-cm diameter) within each of the 14 main plots. Aboveground vegetation of half of the randomly chosen subplots (12 no-neighbors subplots) was removed using chemical nonselective herbicide (Glyphosate) two weeks before target trans- plantations. Glyphosate is a systemic herbicide, taken up via leaves and known to be quickly decomposed in soils (Peltzer and Kochy 2001). Dead vegetation was removed by hand and we used a knife to cut $(20 \mathrm{~cm}$ deep) any roots around the edge of the neighbor-removal areas. The no-neighbor subplots were kept free from vegetation by periodic hand weeding. Periodic inspection and subsequent cutting of any roots entering into the subplots was also performed. One randomly selected individual of each target species was transplanted into the center of each subplot, and we used four subplots as replicates of the species and competition treatments. All planting was completed between 20 May and 5 June 2001. Three weeks later we replaced any dead individuals that had died due to transplant shock. The young targets of the three species had approximately the same life stage (from three to five leaves) at the beginning of the experiment. In summary, the experimental design included 14 environmental plots (two water levels $\times$ seven replicates) with 24 subplots per environmental plot (three species $\times$ two competition levels $\times$ four replicates) with a total of 336 target individuals transplanted into the field experiment.

\section{Measurements and data analyses}

Soil moisture.-Soil samples $\left(\sim 200 \mathrm{~cm}^{3}\right)$ were collected 5-10 cm deep in early August 2002 in three subplots (with or without neighbors) of four plots randomly chosen among the seven replicates of the control plots. The three soil samples of each plot and each competition treatment were pooled and brought to the laboratory in plastic bags immediately after field collection. Soil moisture was determined by drying samples at $105^{\circ} \mathrm{C}$ for $72 \mathrm{~h}$, and was expressed as a percentage of fresh soil mass. Differences in soil moisture between removals and the matrix were analyzed by paired-samples $t$ tests.

Target responses.-Survival and aboveground biomass of transplants were recorded late September 2002, after two years of experimentation. Aboveground biomass of transplants was calculated by clipping living shoots at ground level and drying them at $70^{\circ} \mathrm{C}$ for 72 $\mathrm{h}$ before weighing. Survival was calculated as a percentage per plot for each species and for each competition treatment, whereas the four individual values of biomass per plot and treatments were averaged before analysis to avoid pseudoreplication (Hulbert 1984).

Similar to Suding et al. (2003), individual responses of the three target species to the water treatment were assessed by comparing the performances of transplants (biomass or proportion survival) grown without neighbors in the control plots and the watered plots using the natural-log-transformed response ratio $\left(\ln R_{w}\right)$ : $\ln \mathrm{RR}_{\mathrm{w}}=\ln \left(\frac{\text { target performances in the watered plots }}{\text { target performances in the control plots }}\right)$. 

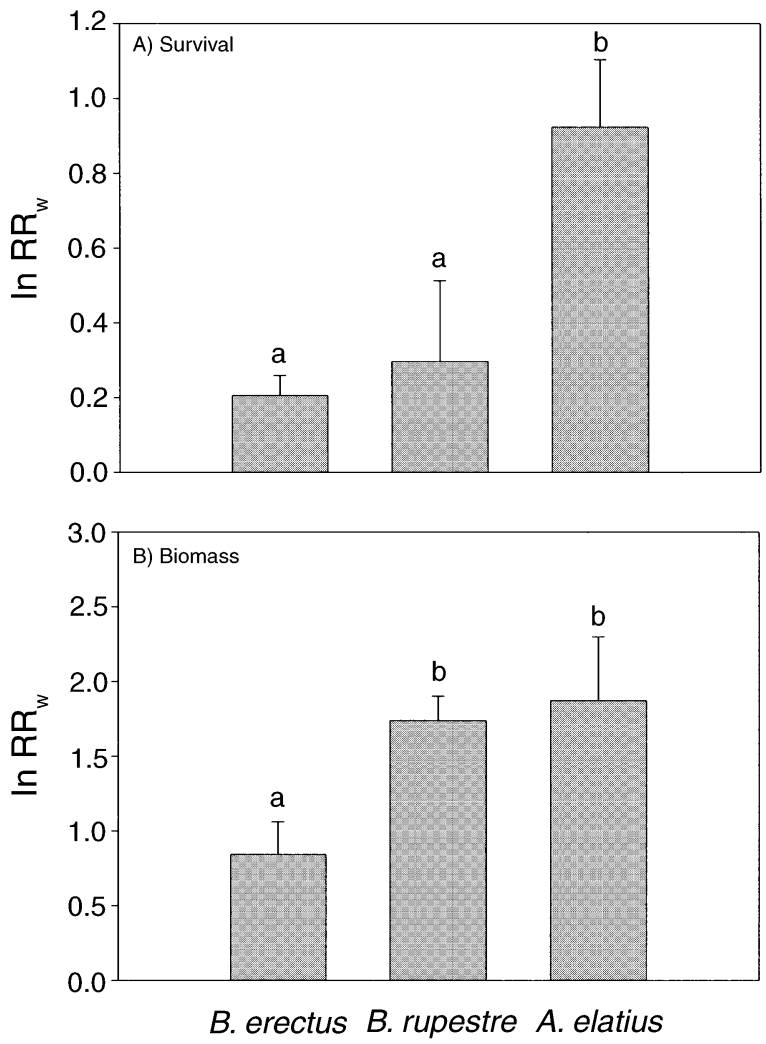

FIG. 1. Response ratio of the three grassland species to the water treatment (ln $R_{\mathrm{w}}$ ) calculated from (A) survival and (B) biomass. (Data are means and SE, $n=7$ replicates.) Letters indicate significant means contrasts among species; bars with the same lowercase letter are not significantly different at $P<0.05$ (Student-Newman-Keuls [SNK] post hoc test). The species are Bromus erectus, Brachypodium rupestre, and Arrhenatherum elatius.

For the responses of the three target species to biotic interactions, the proportional change in performance (biomass or proportion survival) due to the presence of neighbors within the control and the watered plots was quantified per plot, using the natural-log-transformed response ratio $\left(\ln \mathrm{RR}_{\mathrm{n}}\right.$ ), as recommended by Hedges et al. (1999):

$\ln \mathrm{RR}_{\mathrm{n}}=\ln \left(\frac{\text { target performances with neighbors }}{\text { target performances without neighbors }}\right)$.
Values of $\ln \mathrm{RR}$ are symmetrical around 0; positive values indicate a positive effect of the treatment on target performances. For the neighbor treatment, positive values indicate facilitation and negative values indicate competition.

Individual responses to the water treatment $\left(\ln R_{w}\right)$ were analyzed using a one-way ANOVA. Responses of transplants to biotic interactions $\left(\ln R_{n}\right)$ were analyzed using a split-plot ANOVA model where water was treated as a main plot effect and species as a subplot effect. All analyses were carried out with JMP 5.0.1 (SAS Institute 2002).

\section{RESULTS}

Effects of removal on soil moisture in the control plot.-There were significant differences in soil water content between the removals and the matrix in the control plots $(t=4.23, \mathrm{df}=3, P=0.02)$. In the control plots, soil water content was $30 \%$ higher in the matrix than in the no-neighbor subplot.

Individual responses to water.-For all species combined ln $\mathrm{RR}_{\mathrm{w}}$ was positive for the survival and biomass, indicating that water was an important limiting resource at the study site (Fig.1). However, the three target species differed significantly in their survival and growth responses to the water treatment $\left(\mathrm{ln} \mathrm{RR}_{\mathrm{w}}\right.$ : for survival; $F_{2,17}=5.40, P=0.02$; and for biomass, $F_{2,17}=4.19, P=0.03$ ). For survival, Arrhenatherum elatius was much more positively affected by the water treatment than the two other species, Bromus erectus and Brachypodium rupestre, which did not differ significantly from each other (SNK test: $P<0.05$, Fig. 1A). In contrast, the biomass of A. elatius and B. rupestre were much more positively affected by the water treatment than Bromus erectus (SNK test: $P<0.05$ ), but did not differ significantly from each other (Fig. 1B).

Responses to biotic interactions.-For survival $1 n$ $\mathrm{RR}_{\mathrm{n}}$ differed significantly among the three species (Table 1). Survival of $B$. erectus was not affected either positively or negatively by neighboring vegetation in the control plots (no watering). In contrast, Brachypodium rupestre was weakly facilitated and A. elatius strongly facilitated by neighbors. On the other hand, Bromus erectus was competitively excluded in the watered plots, and the two other species were not affected

TABLE 1. Results of split-plot ANOVA for the effect of water and species on competitive response ratio to neighbors $\left(\ln _{\mathrm{n}} \mathrm{R}_{\mathrm{n}}\right.$ ) of three grassland species, calculated from survival and biomass.

\begin{tabular}{|c|c|c|c|c|c|c|c|c|}
\hline \multirow[b]{2}{*}{ Source of variation } & \multicolumn{4}{|c|}{ ln $R R_{n}$, from survival } & \multicolumn{4}{|c|}{ ln $\mathrm{RR}_{\mathrm{n}}$, from biomass } \\
\hline & $\mathrm{df}$ & MS & $F$ & $P$ & df & MS & $F$ & $P$ \\
\hline Water & 1 & 2.735 & 11.01 & 0.006 & 1 & 7.616 & 5.19 & 0.042 \\
\hline Error (main plot) & 12 & 0.250 & & & 12 & 1.480 & & \\
\hline Species & 2 & 1.664 & 12.10 & $<0.001$ & 2 & 17.315 & 34.34 & $<0.0001$ \\
\hline Species $\times$ Water & 2 & 0.196 & 1.42 & 0.262 & 2 & 0.075 & 0.15 & 0.862 \\
\hline Error (subplot) & 23 & 0.138 & & & 23 & 0.504 & & \\
\hline
\end{tabular}



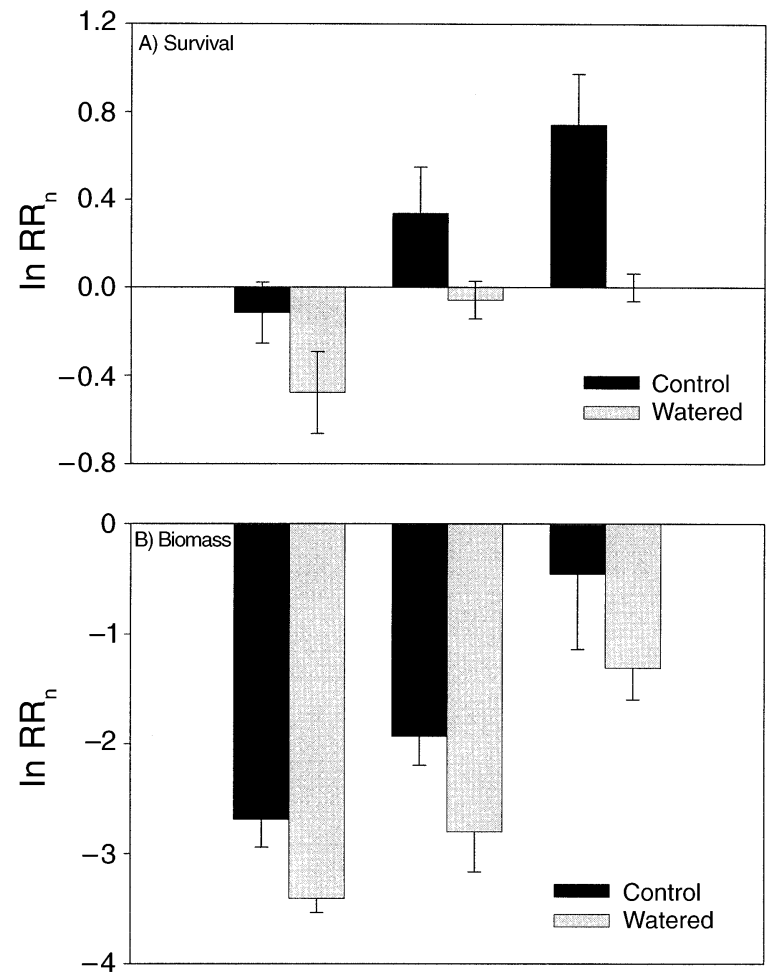

$B$. erectus $B$. rupestre $A$. elatius

FIG. 2. Effect of the water treatment on competitive response to neighbors $\left(\ln \mathrm{RR}_{\mathrm{n}}\right.$ ) of the three grassland species calculated from (A) survival and (B) biomass. (Data are means and SE, $n=7$ replicates.) Species are as in Fig. 1.

by neighbors (Table 1, Fig. 2A). In other words, reducing water stress increased the competition experienced by $B$. erectus and suppressed the facilitation experienced Brachypodium rupestre and A. elatius in control conditions (Fig. 2B).

For biomass, $\ln \mathrm{RR}_{\mathrm{n}}$ also differed significantly among the three species (Table 1). Neighbors negatively affected biomass of all three species, but Bromus erectus was the most affected by competition, Brachypodium rupestre was intermediate, and $A$. elatius was least affected (Fig. 2B). The water treatment significantly decreased $\ln \mathrm{RR}_{\mathrm{n}}$ for biomass of the three species, indicating a general increase in competition intensity as the availability of a limiting resource increased (Fig. 2B, Table 1).

\section{DISCUSSION}

Three co-occurring species in a mesoxeric grassland differed substantially in their responses to enhanced resource supply and to biotic interactions. Consistent with our hypotheses, Brachypodium rupestre and Arrhenatherum elatius were facilitated by neighbors and positively affected by the watering treatment, whereas Bromus erectus was not facilitated and it was the least affected by the watering treatment (hypotheses 1 and 2 ). In addition, A. elatius, the species with the highest competitive-response ability was the most facilitated (hypothesis 3). We found that the ability of these species to tolerate water stress was highly related to their patterns of abundance in European grasslands in general (Royer 1987, Grime et al. 1996). Watering alleviated a limiting factor for A. elatius (i.e., increase in both biomass and survival), less so for Brachypodium rupestre (i.e., increase in biomass), and very little for Bromus erectus. Thus, B. erectus, close to its optimum at the experimental site, was adapted to ambient conditions and was not water stressed. This is consistent with Körner (2003), who argued that environmental conditions are never stressful for species naturally living in a given situation. In contrast, A. elatius and Brachypodium rupestre were not growing in their optimum conditions and were stressed, strongly for the first species and moderately for the second species. This result is rather consistent with Lortie et al. (2004) and Weiher (2004) on the relative nature of limiting factors, which depend on the optima of particular species.

The net outcome of biotic interactions was species specific and depended on resource availability, with facilitation decreasing and competition increasing as abiotic stress was ameliorated (Greenlee and Callaway 1996, Pugnaire and Luque 2001, Maestre et al. 2003). Responses varied depending on whether growth or survival were considered (Schupp 1995, Goldberg et al. 1999, Sans et al. 2002, Franks 2003). For survival, $B$. rupestre and $A$. elatius were facilitated in the control plots and there were no significant net biotic interactions experienced by Bromus erectus. On the other hand, watering suppressed facilitation in Brachypodium rupestre and A. elatius while net outcome of biotic interactions shifted from null to negative for Bromus erectus.

Facilitation may have been driven by the retention of water by vegetation cover, as we found that soil moisture was higher in the controls than in removals. This would explain why the species closest to its distribution optima, B. erectus, did not benefit from neighbor amelioration of soil moisture (Mulder et al. 2001, Pennings et al. 2003). Our study provides experimental evidence that the net outcome of biotic interactions (positive or negative) depends on the fundamental niches of target species (Choler et al. 2001, Bruno et al. 2003). Facilitation may also have been driven by changes in nutrient availability, known to occur in relation with variation in soil moisture. Corcket et al. (2003) observed in the same system a dramatic increase in water and nutrient availability after an experimental shading. However, because facilitation was observed for survival but not for growth, water retention is more likely to be the driving mechanism, consistent with the conclusions of Goldberg and Novoplansky (1997), who argued that variation in nutrient availability is more likely to affect growth than survival (see also Goldberg et al. 2001). Our results for growth support this ar- 
gument because, in opposition to survival, competition for growth was high in the control plots. Watering induced a strong increase in competition for growth, as observed by a number of authors along natural or experimental gradients of water availability (Kadmon 1995, Corcket et al. 2003). Variation in pulse frequency may also have driven this increase in competition for growth with watering. Goldberg and Novoplansky (1997) have argued that competition for growth is low in xeric habitats because resource uptake mainly occurs during pulse (wet) periods, which are rare. Because we used a permanent irrigation system for our watering treatment, water pulses occurred more often in the watered vs. the control plots, which depended only on natural rainfall events. Thus, nutrients may have been more available in the watered plots, increasing competition for growth compared to the control plots.

Our results showed that the three target species differed in their competitive response ability. When watered, B. erectus had a much lower competitive response ability than the two other species. Ryser and Lambers (1995) demonstrated that fast-growing species, such as $A$. elatius, had better nutrient uptake rates than slow-growing species. Competition for soil nutrients may explain the high competitive-response ability of A. elatius for growth.

We observed a trade-off between tolerance ability and competitive-response ability (Grime 1979, Greiner La Peyre et al. 2001, Suding et al. 2003). In other words, the species with the least tolerance to the abiotic conditions and highest competitive-response ability was also the most facilitated by neighbors. We showed that this trade-off is of great importance in the net outcome of biotic interactions. Dormann and Brooker (2002) demonstrated the existence of competitive interactions even in harsh condition such as arctic tundra, with both negative and positive interactions occurring at the same time as has been found in other ecosystems (Callaway 1995, Callaway and Walker 1997, Holmgren et al. 1997, Pugnaire and Luque 2001, Maestre et al. 2003). Our study represents a field-based, mechanistic demonstration of facilitation as a function of both low stress tolerance (deviation from optimal) and high competitive-response ability of species. A high competitive-response ability and a low stress tolerance enable a species to minimize the cost of negative interactions and to maximize the benefits of habitat amelioration by neighbors. Holmgren et al. (1997) proposed a conceptual model dealing with the interplay of competition and facilitation along a water gradient, based on a trade-off between shade and drought tolerance for nurse species canopies (trees or shrubs) and seedlings (see also Holmgren 2000). Our study provides a more general application of Holmgren's framework as our target species belong to the same canopy strata and negative effects other than shading may be involved in the trade-off.
The fact that facilitation was important in a habitat (mesoxeric grassland) not considered to be particularly harsh at the global scale (i.e., in comparison to alpine or desert communities), but depended on the fundamental niche optima of the target species and their relative positions vs. these optima, has strong implications for the mechanisms underlying coexistence and diversity in these generally species-rich communities (Hacker and Gaines 1997, Mulder et al. 2001). The subordinate status of a species appears to be determined to a large degree either by negative interactions at the favorable end of its distributional curve or by stress and facilitation extending its realized niche and allowing the species to occur and persist beyond its fundamental niche (Hacker and Bertness 1999, Bruno et al. 2003). If considered as intrinsic to a species, high competitive-response ability should have a strong effect on the width of its distributional curve, enabling the species to cope with strong competition on the favorable end of the curve and to maximize benefits of habitat amelioration on the other end. In very harsh environments the probability of finding species that are occurring outside their fundamental niche optima is high, and this may be why so many studies report an increase in the general importance of positive interactions in communities occurring in relatively stressful habitats (e.g., unusually saline, cold, or hot) (Bertness and Callaway 1994, Choler et al. 2001, Bruno et al. 2003, Lortie et al. 2004).

Our study focused on the response of species (beneficiaries/focal species) to diffuse interactions (Wilson and Keddy 1986). However, facilitative outcome can be understood as being the result of complex interactions between the response of beneficiary species (stress tolerance and competitive-response ability) and effects of benefactors (habitat amelioration and interference). Benefactors can differ in their ability to negatively or positively affect the focal species (i.e., competitive/facilitative effects) and environmental conditions would also influence facilitative or competitive effects of benefactors (Tewksbury and Loyd 2001, Maestre and Cortina 2004). Moreover, species-specific effects (positive or negative) provided by direct (e.g., mycorrhizal mediated interactions, allelopathy), or indirect (e.g., attraction of pollinators, attraction of herbivores) interactions are common in nature (Callaway 1998) and may create less predictable relationships among facilitation, stress tolerance, and competitiveresponse ability.

As Brooker and Callaghan (1998) proposed, our study showed that facilitative outcome is a function of components of the species response-these include at least the stress tolerance and the competitive-response ability of target species. Plant traits associated with tolerance and competitive-response ability should provide valuable information to predict facilitative outcome in plant communities. However, because an interaction involving the same pair of species may change 
along a particular environmental gradient (Maestre and Cortina 2004), this prediction may not match all along the gradient. Traits associated with optimal life in a particular environment may predict the absence of facilitation, but traits differing from the optimal may predict facilitation or competition depending on the side of the fundamental niche of the species considered (i.e., if the particular environment corresponds to the adverse or the favorable end of the distributional curve of the species). The same predictions might be made based upon broad distributions of a particular species (Choler et al. 2001). Further manipulations of limiting resources or conditions in the field that distinguish competitive/facilitative effects from competitive/facilitative responses, and that consider the relative aspect of stress depending on the fundamental niche optimum of species, may provide a better understanding of the mechanisms (e.g., the environment, competition, facilitation) underlying variation in abundance/dominance patterns, coexistence, and biodiversity along ecological gradients.

\section{ACKNOWLEDGMENTS}

We thank P., J., and K. Vianey-Liaud, the owners of the grassland, who allowed us to conduct this experiment in their field. We are particularly grateful to M. Brun for the technical assistance, the maintaining of this experiment, and in particular the watering treatment. We thank many friends and colleagues-A. Bouasria, P. Boissière, B. Château, Th. Commeau, E. Corket, V. Darmuzey, G. Gomez, N. Gross, L. Liancourt, L. Menduni, Th. Morand, E. Michalet, A. Michalet, G. Stutz, C. Spano, M. Tilquin, and F. Viard-Crétat-for help with field work and data collection. We are grateful to Ph. Choler, J. de Chazal, S. C. Pennings, and two anonymous reviewers for their valuable comments on the manuscript.

\section{Literature Cited}

Bertness, M. D., and R. M. Callaway. 1994. Positive interactions in communities. Trends in Ecology and Evolution 9:191-193.

Bertness, M. D., L. Gough, and S. W. Shumway. 1992. Salt tolerances and the distribution of fugitive salt marsh plants. Ecology 73:1842-1851.

Bertness, M. D., and S. D. Hacker. 1994. Physical stress and positive associations among marsh plants. American Naturalist 144:363-372.

Brooker, R. W., and T. V. Callaghan. 1998. The balance between positive and negative plant interactions and its relationship to environmental gradients: a model. Oikos 81: 196-207.

Bruno, J. F., J. J. Stachowicz, and M. D. Bertness. 2003. Inclusion of facilitation into ecological theory. Trends in Ecology and Evolution 18:119-125.

Callaway, R. M. 1995. Positive interactions among plants. Botanical Review 61:306-349.

Callaway, R. M. 1998. Are positive interactions species-specific? Oikos 82:202-207.

Callaway, R. M., R. W. Brooker, P. Choler, Z. Kikvidze, C. J. Lortie, R. Michalet, L. Paolini, F. I. Pugnaire, B. Newingham, E. T. Aschehoug, C. Armas, D. Kikidze, and B. J. Cook. 2002. Positive interactions among alpine plants increase with stress. Nature 417:844-848.

Callaway, R. M., and L. R. Walker. 1997. Competition and facilitation: a synthetic approach to interactions in plant communities. Ecology 78:1958-1965.
Castro, J., R. Zamora, J. A. Hodar, and J. M. Gomez. 2002. Use of shrubs as nurse plants: a new technique for reforestation in Mediterranean mountains. Restoration Ecology 10:297-305.

Choler, P., R. Michalet, and R. M. Callaway. 2001. Competition and facilitation on gradients in alpine communities. Ecology 82:3295-3308.

Corcket, E., P. Liancourt, R. M. Callaway, and R. Michalet. 2003. The relative importance of competition for two dominant grass species, as affected by environmental manipulations in the field. Ecoscience 10:186-194.

Dormann, C. F., and R. W. Brooker. 2002. Facilitation and competition in the High Arctic: the importance of experimental approach. Acta Oecologica 23:297-301.

Franks, S. J. 2003. Competitive and facilitative interactions within and between two species of coastal dune perennials. Canadian Journal of Botany 81:330-337.

Goldberg, D., and K. Landa. 1991. Competitive effect and response: hierarchies and correlated traits in the early stages of competition. Journal of Ecology 79:1013-1030.

Goldberg, D. E., and A. Novoplansky. 1997. On the relative importance of competition in unproductive environments. Journal of Ecology 85:409-418.

Goldberg, D. E., T. Rajaniemi, J. Gurevitch, and A. StewartOaten. 1999. Empirical approaches to quantifying interaction intensity: competition and facilitation along productivity gradients. Ecology 80:1118-1131.

Goldberg, D. E., R. Turkington, L. Olsvig-Whittaker, and A. R. Dyer. 2001. Density dependence in an annual plant community: variation among life history stages. Ecological Monographs 71:423-446.

Greenlee, J. T., and R. M. Callaway. 1996. Abiotic stress and the relative importance of interference and facilitation in montane bunchgrass communities in western Montana. American Naturalist 148:386-396.

Greiner La Peyre, M. K., E. Hahn, I. A. Mendelssohn, and J. B. Grace. 2001. The importance of competition in regulating plant species abundance along a salinity gradient. Ecology 82:62-69.

Grime, J. P. 1979. Plant strategies and vegetation processes. John Wiley and Sons, Chichester, UK.

Grime, J. P., and B. D. Campbell. 1991. Growth rate, habitat productivity, and plant strategy as predictors of stress response. Pages 143-159 in H. A. Mooney, W. E. Winner, and E. J. Pell, editors. Responses of plants to multiple stresses. Academic Press, New York, New York, USA.

Grime, J. P., and A. V. Curtis. 1976. The interaction of drought and mineral nutrient stress in calcareous grassland. Journal of Ecology 64:975-988.

Grime, J. P., J. G. Hodgson, and R. Hunt. 1996. Comparative plant ecology: a functional approach to common British species. Unwin Hyman, London, UK.

Hacker, S. D., and M. D. Bertness. 1999. Experimental evidence for factors maintaining plant species diversity in a New England salt marsh. Ecology 80:2064-2073.

Hacker, S. D., and S. D. Gaines. 1997. Some implications of direct positive interactions for community species diversity. Ecology 78:1990-2003.

Hastwell, G. T., and J. M. Facelli. 2003. Differing effects of shade-induced facilitation on growth and survival during the establishment of a chenopod shrub. Journal of Ecology 91:941-950.

Hedges, L. V., J. Gurevitch, and P. S. Curtis. 1999. The metaanalysis of response ratios in experimental ecology. Ecology 80:1150-1156.

Hillier, S. H. 1990. Gaps, seed banks, and plant species diversity in calcareous grasslands. Pages 57-66 in D. W. H. Walton and D. A. Wells, editors. Calcareous grasslands: ecology and management. Bluntisham Books, Huntingdon, UK. 
Holmgren, M. 2000. Combined effects of shade and drought on tulip poplar seedlings: trade-off in tolerance or facilitation? Oikos 90:67-78.

Holmgren, M., M. Scheffer, and M. A. Huston. 1997. The interplay of facilitation and competition in plant communities. Ecology 78:1966-1975.

Holzapfel, C., and B. E. Mahall. 1999. Bi-directional facilitation and interference between shrubs and annuals in the Mojave desert. Ecology 80:1747-1761.

Hulbert, S. H. 1984. Pseudoreplication and the design of ecological field experiments. Ecological Monographs 54: 187-211.

Kadmon, R. 1995. Plant competition along soil moisture gradients: a field experiment with the desert annual Stipa capensis. Journal of Ecology 83:253-262.

Körner, C. 2003. Limitation and stress-always or never? Journal of Vegetation Science 14:141-143.

Lortie, C. J., R. W. Brooker, Z. Kikvidze, and R. M. Callaway. 2004. The value of stress and limitation in an imperfect world: a reply to Körner. Journal of Vegetation Science 15: 577-580.

Maestre, F. T., S. Bautista, and J. Cortina. 2003. Positive, negative, and net effects in grass-shrub interactions in Mediterranean semiarid grasslands. Ecology 84:31863197.

Maestre, F. T., S. Bautista, J. Cortina, and J. Bellot. 2001. Potential for using facilitation by grasses to establish shrubs on a semiarid degraded steppe. Ecological Applications 11: 1641-1655.

Maestre, F. T., and J. Cortina. 2004. Do positive interactions increase with abiotic stress? A test from a semi-arid steppe. Proceedings of the Royal Society of London, Series B 271(Supplement):S331-S333.

Méteo-France. 2001, 2002. Bulletin climatologique annuel de l'Isève. Saint-Martin d'Hères, Grenoble, France.

Mulder, C. P. H., D. D. Uliassi, and D. F. Doak. 2001. Physical stress and diversity-productivity relationships: the role of positive interactions. Proceedings of the National Academy of Sciences (USA) 98:6704-6708.

Peltzer, D. A., and M. Köchy. 2001. Competitive effects of grasses and woody plants in mixed-grass prairie. Journal of Ecology 89:519-527.
Pennings, S. C., E. R. Seling, L. T. Houser, and M. D. Bertness. 2003. Geographic variation in positive and negative interactions among salt marsh plants. Ecology 84:15271538.

Pugnaire, F. I., and M. Luque. 2001. Changes in plant interactions along a gradient of environmental stress. Oikos 93: 42-49.

Royer, J. M. 1987. Les pelouses des Festuco-Brometea. D'un exemple régional à une vision eurosibérienne: étude phytosociologique et phytogéographique. Dissertation. Université de Franche-Comté, Besançon, France.

Ryser, P., and H. Lambers. 1995. Root and leaf attributes accounting for the performance of fast- and slow-growing grasses at different nutrient supply. Plant and Soil 170:251265 .

Sans, X. F., J. Escarré, J. Lepart, and F. Hopkins. 2002. Positive vs. negative interactions in Picris hieracioides L., a mid-successional species of Mediterranean secondary succession. Plant Ecology 162:109-122.

SAS Institute. 2002. JMP 5.0.1. SAS Institute, Cary, North Carolina, USA.

Schupp, E. W. 1995. Seed-seedling conflicts, habitat choice, and patterns of plant recruitment. American Journal of Botany 82:399-409.

Suding, K. N., D. Goldberg, and K. M. Hartman. 2003. Relationships among species traits: separating levels of response and identifying linkages to abundance. Ecology 84: $1-16$.

Tewksbury, J. J., and J. D. Loyd. 2001. Positive interactions under nurse-plants: spatial scale, stress gradients and benefactor size. Oecologia 127:425-434.

Tielbörger, K., and R. Kadmon. 2000. Temporal environmental variation tips the balance between facilitation and interference in desert plants. Ecology 81:1544-1553.

Walker, L. R., and F. S. Chapin, III. 1986. Physiological controls over seedling growth in primary succession on an Alaskan floodplain. Ecology 67:1508-1523.

Weiher, E. 2004. Why should we constrain stress and limitation? Why conceptual terms deserve broad definitions. Journal of Vegetation Science 15:569-571.

Wilson, S. D., and P. A. Keddy. 1986. Measuring diffuse competition along an environmental gradient: results from a shoreline plant community. American Naturalist 127: 862-869. 